\title{
Factors influencing the composition and balance of foals' microbiota
}

\author{
Fatores que influenciam a composição e equilíbrio da microbiota de potros \\ Factores que influyen la composición y el equilibrio de la microbiota del potrillo
}

Received: 07/01/2021 | Reviewed: 07/11/2021 | Accept: 07/12/2021 | Published: 07/22/2021

\author{
Mariana Andrade Mousquer \\ ORCID: https://orcid.org/0000-0001-8253-3713 \\ Universidade Federal de Pelotas, Brasil \\ E-mail: mmousquer.vet@gmail.com \\ Tatiane Leite Almeida \\ ORCID: https://orcid.org/0000-0001-7517-7087 \\ Universidade Federal de Pelotas, Brasil \\ E-mail: tatianeleitealmeida@gmail.com \\ Rafaela Pinto de Souza \\ ORCID: https://orcid.org/0000-0003-0662-6728 \\ Universidade Federal de Pelotas, Brasil \\ E-mail: rafaelapsvet@gmail.com \\ Vitória Müller \\ ORCID: https://orcid.org/0000-0002-4585-6772 \\ Universidade Federal de Pelotas, Brasil \\ E-mail: mullervitoria@hotmail.com \\ Eliza Moreira Piemolini \\ ORCID: https://orcid.org/0000-0002-6415-1567 \\ Universidade Federal de Pelotas, Brasil \\ E-mail: elizapiemolini@hotmail.com \\ Bruna da Rosa Curcio \\ ORCID: https://orcid.org/0000-0001-8678-3816 \\ Universidade Federal de Pelotas, Brasil \\ E-mail: curciobruna@hotmail.com \\ Carlos Eduardo Wayne Nogueira \\ ORCID: https://orcid.org/0000-0002-8555-7953 \\ Universidade Federal de Pelotas, Brasil \\ E-mail: cewn@terra.com.br
}

\begin{abstract}
Horses are extremely dependent on the correct functioning of the digestive system for energy production and the performance of their physiological functions. The intestinal microbiota plays a key role in maintaining health, being related to the modulation of the immune system, protection against pathogenic microorganisms and also for obtaining nutrients. Due to the importance of the microbiota in maintaining health from the beginning of life, this review aims to address the early composition, development and factors that influence the intestinal microbiota in foals. A qualitative review was carried out in the main research databases. Data referring to the early microbial colonization suggest that it occurs since intrauterine life, despite the fact that at birth, the foals acquire a large part of the microorganisms that will form its microbiota. The main phyla involved in this process are Proteobacteria, Firmicutes, Actinobacteria and Bacteroidetes, which are aquired from a combination of bacteria present in the feces, vagina and other maternal environments. From birth until the first weeks of life, the microbiota gradually changes due to several factors, which include the composition of food, coprophagy, exposure to different environments and medications. The foal's microbiota becomes more stable in the first and second months of life. It is suggested that changes in the composition (dysbiosis) and diversity of the different phyla are a risk factor for the development of diseases, since the microbiota directly influences the immune system. From advances in sequencing technologies it was possible to investigate the components and factors associated with early colonization of microbiota in horses as well as factors related to the development of dysbiosis and disease. Nevertheless, many facts are still unclear and should be adressed in the future.
\end{abstract}

Keywords: Immune system; Gut microbiota; Intestinal flora; Equine microbiota.

\section{Resumo}

Os equinos são animais extremamente dependentes do correto funcionamento do sistema digestivo para a produção de energia e o desempenho das suas funções fisiológicas. A microbiota intestina tem papel fundamental na manutenção da saúde, estando ligada tanto a modulação do sistema imune e proteção contra microrganismos patogênicos quanto com a obtenção de nutrientes. Devido a importância da microbiota na manutenção da saúde desde o início da vida, essa revisão tem por objetivo abordar a composição inicial, desenvolvimento e os fatores que influenciam no equilíbrio da microbiota intestinal em potros. Foi realizada uma revisão qualitativa de trabalhos que abordam o 
assunto nas principais bases de pesquisa. Dados referentes a colonização microbiana inicial sugerem que esta ocorra desde o período de vida intrauterina, apesar de ser no parto, o momento em que o potro adquire grande parte dos microoganismos que formarão sua microbiota. Os principais filos envolvidos nesse processo são Proteobacteria, Firmicutes, Actinobacteria and Bacteroidetes, provenientes de uma combinação de bactérias presentes nas fezes, vagina e outros ambientes maternos. A partir do nascimento até as primeiras semanas de vida a microbiota muda gradualmente devido a diversos fatores, os quais incluem a composição da alimentação, coprofagia, exposição a diferentes ambientes e medicações. A microbiota do potro se torna mais estável no primeiro e segundo mês de vida. É sugerido que alterações na composição (disbiose) e diversidade dos diferentes filos são um fator de risco para o desenvolvimento de doenças, uma vez que a microbiota influencia diretamente no sistema imune. A partir dos avanços nas tecnologias de sequenciamento foi possível investigar melhor os componentes e fatores associados a colonização inicial da microbiota nos equinos tanto quanto fatores correlacionados ao desenvolvimento de disbiose e doenças. Apesar disso, muitos fatos sobre o assunto ainda não foram esclarecidos e merecem ser estudados no futuro.

Palavras-chave: Sistema imune; Microbiota intestinal; Flora intestinal; Microbiota equina.

\section{Resumen}

Los equinos son animales que dependen extremadamente del correcto funcionamiento del sistema digestivo para la producción de energía y el desempeño de sus funciones fisiológicas. La microbiota intestinal tiene un papel fundamental en el mantenimiento de la salud, estando vinculada tanto a la modulación del sistema inmunológico y la protección frente a microorganismos patógenos como a la obtención de nutrientes. Debido a la importancia de la microbiota en el mantenimiento de la salud desde el inicio de la vida, esta revisión tiene como objetivo abordar la composición inicial, el desarrollo y los factores que influyen en el equilibrio de la microbiota intestinal en los potrillos. Se realizó una revisión cualitativa de trabajos que abordan el tema en las principales bases de investigación. Los datos referentes a la colonización microbiana inicial sugieren que se da desde el período de la vida intrauterina, a pesar de estar al nacer, momento en el que el potro adquiere gran parte de los microorganismos que formarán su microbiota. Los principales phyla involucrados en este proceso son Proteobacteria, Firmicutes, Actinobacteria y Bacteroidetes, provenientes de una combinación de bacterias presentes en las heces, vagina y otros ambientes maternos. Desde el nacimiento hasta las primeras semanas de vida, la microbiota cambia gradualmente debido a varios factores, que incluyen la composición de los alimentos, la coprofagia, la exposición a diferentes ambientes y medicamentos. La microbiota del potro se vuelve más estable en el primer y segundo mes de vida. Se sugiere que los cambios en la composición (disbiosis) e diversidad de los diferentes phyla son un factor de riesgo para el desarrollo de enfermedades, ya que la microbiota influye directamente en el sistema inmunológico. A partir de los avances en las tecnologías de secuenciación, fue posible investigar mejor los componentes y factores asociados a la colonización inicial de la microbiota en equinos, así como los factores relacionados con el desarrollo de disbiosis y enfermedades. A pesar de esto, muchos hechos sobre el tema aún no se han aclarado y merecen ser estudiados en el futuro.

Palabras clave: Sistema inmunológico; Microbiota intestinal; Flora intestinal; Microbiota equina.

\section{Introduction}

Horses are herbivores with a unique gastrointestinal tract (GIT) when compared to other domestic animals. These animals are highly dependent on their anatomy for energy production, since the colon and cecum are the main areas where fibrinolytic bacteria perform fermentation and produce short chain fatty acids, which are used as energy source (Costa \& Weezze, 2012; Quercia et al., 2018). The intestinal microbiota is one of the most diverse ecosystems, harboring different microorganisms, including protozoa, viruses, fungi and anaerobic bacteria that colonize the intestines since intrauterine life (Turnbaugh, 2009; Fernandes et al., 2014, Mols et al., 2020).

The microbiota is essential for health mantainance, being responsible for development of the digestive system, for stimulating and modulating the immune system, protecting the individual against pathogenic microorganisms, improving digestion and capturing energy from food (Backhed, 2004; Russell, 2013; Alarcón, 2016). It acts simultaneously with host cells through a symbiosis process (Saad, 2006). Its balance results in a normal performance of the individual's physiological functions and can ensure a better quality of life (Fanaro, 2003). In contrast, the imbalance, also called dysbiosis, can be a predisposing factor for the occurrence of diseases, such as enterocolitis (Harlow, 2013; Schoster et al., 2017; De La Torre et al., 2018), laminitis (Steelman et al, 2012; Moreau, 2014), colic (Weese et al., 2015), and, in humans it has been associated with several other diseases (Gosalbes et al,. 2012; Toh and Allen- vercoe, 2015; Wang et al., 2018).

In foals, as well as already demonstrated in humans (Aagaard et al., 2014), it is suggested that GIT colonization 
begins in the uterine environment (Quercia et al., 2018; Mols et al., 2020). The foal initially has a transient microbiota, highly susceptible to changes due to diet and environment. It becomes more stable and similar to the microbiota of an adult horse when the foal reaches 50- 60 days of life (Costa, 2016; Lindenberg et al. 2019). The microbiota residing in adult horses is mainly composed of bacteria from the phyla Firmicutes, Bacteroidetes and Verrucomicrobia (De La Torre et al., 2018; Husso et al., 2020).

Due to the importance of the microbiota in the maintainance of health and because it is an emerging subject, several studies have directed attention to colonization, composition and development of the microbiota since peripartum (Quercia et al., 2018; Husso et al; 2020). Thus, this review aims to address the initial composition, development and the factors that influence the balance of the intestinal microbiota in foals.

\section{Methodology}

The present study was carried out as a qualitative literature review (Pereira et al., 2018), based on a prospecting bibliographic search performed on the main referential databases available in eletronic environment like Mendeley, MEDLINE, pubMed and SciELO. From the data found, it was possible to discuss the main phyla involved in the composition of the foal microbiota since early life along with some important factors that implicate its healthy development.

\section{Foal microbiota}

\subsection{Development and composition of the early microbiota}

The uteroplacental unit used to be considered a sterile environment for the foal, and the presence of microorganisms in culture of the placenta and/or amniotic fluid were considered as an indicatitive of infection (Prince et al., 2015). However, a histological study in humans using fetal membranes from healthy pregnancies identified the presence of bacteria (Steel et al., 2005). Later on, Aagaraard et al. (2013) identified the presence of several microbial populations in healthy placentas of Rhesus monkeys, indicating that the colonization of the microbiota in the fetus may start in the intrauterine life. From the development of new sequencing technologies, several studies have been performed in mammals suggesting the interaction of the microbiota between mother and fetus (Aagard et al., 2013; Quercia et al., 2019; Mols et al., 2020).

Similarly, in the equine species, it was believed that the foal would develop in an aseptic intrauterine environment and would acquire its initial microbiota from birth canal and external environment (Earing et al., 2012; Faubladier et al., 2013). However, Hemberg et al. (2015) identified bacterial growth in the amniotic fluid of healthy pregnancies, and recently, Quercia et al. (2019) observed the presence of bacterial DNA in the amniotic fluid of mares carrying healthy pregnancies by using metagenomics analysis (next generation sequencing- NGS). In addition, a variaty of microorganisms were also identified in foals' meconium (Jacquay et al., 2018, Quercia et al., 2019; Husso et al., 2020).

Despite not knowing how the intrauterine microbial colonization occurs, it is believed that it is necessary to start modulation of the immune system and plays a key role in the development of health and disease prevention (Costa et al., 2016). Some hypotheses about the natural colonization routes have been suggested from studies carried out in humans and rodents (Mols et al, 2020). Among them, the three most accepted ones include: the progression of microorganisms in an ascending way through the vagina and the cervix to the uterus; hematogenous migration from the oral cavity or GIT to the placenta and, finally, bacterial translocation by migration of dendritic cells from the intestinal lumen to the placenta (Prince et al., 2015; Mols et al., 2020). In equine species, although none of these hypotheses have been proven and colonization routes during the uterine life remain unknown, Quercia et al. (2019) suggested the existence of an internal route of microorganisms transmission between mother and fetus through the sharing of 32 and 75 OTUs (operational taxonomic units) between 
meconium and amniotic fluid and between meconium and maternal TGI, respectively.

Many microorganisms that are associated with diseases, such as endometritis and placentitis, including Streptococcus spp., Staphylococcus spp., Pseudomonas spp. and E. coli. are present in the amniotic fluid of healthy pregnancies, without necessarily cause any problem (Quercia et al., 2020; Mols et al., 2020). The fact that these bacteria are involved in only a few disease cases, suggests that the stability of the microbiota is important for maintaining health, while the imbalance of some microbial population can lead to the occurrence of dysbiosis and thus lead to the development of disease (Mols et al., 2020).

The moment of birth is when the foal acquires several microorganisms that will form the initial microbiota (Husso et al., 2020). Colonization is very dynamic and changes significantly after the first day of life (Costa, 2016; Lindenberg et al., 2019). Meconium microbiota is basically composed of a combination of bacteria present in feces, vagina, and other maternal environments, mainly from the phyla Proteobacteria, Firmicutes, Actinobacteria and Bacteroidetes (Jacquay et al., 2018; Quercia et al., 2019; 2019; Husso et al., 2020). These phyla are basically involved in the digestion and fermentation of different dietary compounds such as proteins, sugars and fibers. Some of these families are recognized as indicators of intestinal health because they are associated with modulation of the immune response and protection against different pathogens (De La Torre et al., 2019).

Nevertheless, some differences in the predominance of phyla and genera that compose microbiota were identified in foals over the first 24 hours after birth (Faubladier et al., 2013; Costa et al., 2016; De La Torre et al. 2019; Husso et al., 2020). The first groups involved in the breakdown of carbohydrates that have been identified are anaerobic bacterica, mainly amylolytic and lactate users, such as streptococci and lactobacilli (Faubladier et al., 2013). Some authors found variable dominance between the phyla Firmicutes and Proteobacteria (Costa et al. 2016; De La Torre et al. 2019), and different genera associated with the development of diseases such as Escherichia/Shigella and Clostridium spp. (Husso et al. 2020). Members of the phylum Bacteroidetes genera Bacteróides have also been detected in most foals (Husso et al., 2020).

These differences observed among studies suggest that the environment and management in which the animals are raised has a great influence on the genera richness present in the intestinal microbiota. It was observed that foals from the same herd have similar microbiota, but diferences in the predominance of phyla where found when compared with those from studies carried out in different places. Corroborating to this idea, a study performed by De La Torre et al. (2019) found diferences in bacterial colonization in foals from different properties submitted to different managements. Furthermore, Tavanner et al. (2020) identified greater taxonomic diversity in the microbiota of foals kept in the field when compared to those kept in stalls, which indicates that management is a determining factor.

The foal microbiota gradually changes over the first three days of life. During this period, the meconium microbiota is lost and the foal acquires fiber fermenting microorganisms, such as Enterococcus spp. and Enterobacteriaceae, through colostrum and milk intake (Quercia et al. 2019). Thus, this is considered an important source for the establishment of the microbiota (Quercia et al. 2019). In the first weeks of life, foals also initiate some typical behaviors related to the species, such as coprophagy, and start the consumption of forage and concentrate, which will also influence the colonization of the intestinal microbiota (Quercia et al., 2019; Pyles et al., 2020). Thereat, from 7 days onwards, there is a more abundant growth of fiberfermenting bacteria.

At this point, the most abundant phylum is Firmicutes (Costa et al., 2016; Husso et al., 2020). The most abundant genera according to De La Torre et al. (2019) and Husso et al. (2020) is Bacteróides, which is found in the vaginal mucosa of mares and its increase is also directly related to the introduction of other foods besides milk. Other authors have also observed a greater abundance of this genera in foals between 30 and 50 days of life (Bordin et. Al., 2013, Lindenberg et al. 2019). After the first week of life, there is a more abundant growth of fiber-fermenting bacteria, but the microbiota composition of foals is still quite divergent from adult horses at this point (Lindenberg et al 2019; Liu et al., 2020). 
The increase in intestinal microbiota diversity and similarity with the maternal microbiota composition are associated with maturation of the gastrointestinal tract in humans and mice (Backhed, 2015; Flemer, 2017). In foals, some studies indicate different times when the intestinal microbiota becomes closer in terms of the composition of the maternal microbiota (Faubladier et al., 2013; De La Torre et al., 2019; Quercia et al., 2019). Kuhl et. al. (2011) and De La Torre et al. (2019) found similarities between the microbiota of mares and foals aged 28 to 30 days. Besides, only few changes in bacterial communities in foals' macrobiota were found after two months of life, and most of them related to the type of food ingested (De La Torre et al., 2019). In the other hand, other authors suggested that microbiota stability is achieved only around 50 - 60 days of life (Costa et al., 2016; Lindemberg et al., 2019).

\subsection{Maternal microbiota}

It is known that the composition of the equine microbiota can vary according to the environment, management, age and also due to individual variations (Mols et al., 2020). The foal is exposed to a large amount of bacteria during the peripartum period through the contact with the materal fecal, vaginal and oral microbiota as well as the microorganisms found in the mare's milk (Mols et al., 2020).

The fecal microbiota of the pregnant mare is mainly composed by bacteria from the phyla Firmicutes and Bacteriodetes, with relative abundance of the families Lachnospiraceae and Rumonicoccaceae, among others in the order Bacteroidales and family Prevotellaceae (Husso et al. 2020). After birth, part of the foal's microbiota is acquired from the maternal fecal microbiota (Husso et al., 2020). The sharing of different bacteria (75 OPUs) between the mares' feces and the foal's meconium was identified: Clostridium, Enterococcus, Ruminococcaceae, Lactococcus lactis, Bacteróides and Bacillus (Quercia et al., 2019).

Regarding the oral microbiota, data from humans suggest the relationship between periodontal pathogenic bacteria and the occurrence of premature births (Cobb et al., 2017). Few data about oral microbiota in horses are available. A study demonstrated a similarity on mares and humans oral microbiota, but with a lower amount of the phylum Bacteroidetes and dominance of the genera Gemella from the phylum Firmicutes in the mares, which is associated with good oral health (Husso et al. 2020). In that same study, the maternal oral microbiota was compared with the composition of the fecal microbiota at birth, and the sharing of only $0.23 \%$ of the DNA sequences was observed.

The vaginal microbiota is much less diverse than the fecal one and there is greater individual variation. The most abundant genera identified were: Corynebacterium, Porphyromonas, Helcococcus and Campylobacter (Husso et al., 2020). Other genera found in the vaginal microbiota include Lactobacillus, Enterococcus and Fusobacterium (Mols et al., 2020). Many bacteria characterized in the foal's early microbiota are compatible with those existing exclusively in the mare's vagina, which suggests that the birth canal is an important colonization rout of the foal's GIT (Husso et al., 2020). Furthermore, many bacteria found in the vagina are part of the uterine microbiota (Mols et al., 2020).

The colostrum in turn is not only rich in immunoglobulins, growth factors and other important compounds for the newborn's health and maturation of the GIT, but is also a source of microorganisms (Kuhl et al., 2011; Lindemberg et al., 2019). It is composed mostly of Enterobacteriaceae and Enterococcus, which are acquired by the newborn in the first days of life (Quercia et al., 2019).

\subsection{Coprophagic behavior}

Coprophagy is a common behavior among foals and it is observed in neonates as early as three days of life with a peak at 14 days (Pyles et al., 2020). It remains more pronounced in the first two months of life, and occurs every four to nine hours (Croell-Davis, 1985; Crowell-Davis, 1989). 
Between the third and fifth days of life, when coprophagia episodes begin, foals acquire microorganisms belonging to the adult flora, such as Prevotella, Blautia and Ruminococcus, which are responsible for the degradation of fibers in the diet (Quercia et al. 2019). Feces ingestion is essential to acquire microorganisms necessary for the fermentation of fibrous feed in adulthood (Geor, 2013) and this behavior can contribute to the stabilization of the microbiota, since it provides a constant source of microorganisms (Crowell-Davis, 1985; Pyles et al., 2020).

\subsection{Foal heat diarrhea}

It is a transient diarrhea in foals, commonly known as foal heat diarrhea, that occurs between $5-15$ days of life (Magdesian 2005). It is named this way because its occurrence coincide with the mare's first postpartum heat (Magdesian 2005, Kuhl et al. 2011). It is mostly self-limiting and characterized by no systemic compromisse (Magdesian 2005).

It was previously believed to be caused by changes in milk composition, as a result of hormonal changes caused by the first postpartum estrus. However, this was ruled out as a cause, as orphan foals also develop diarrhea in the same period (Magdesian 2005; Kuhl et al., 2011), and no relationship was identified between the milk composition during the period of the first postpartum heat and the appearance of diarrhea in foals (Johnston, Kamstra and Kohler, 1970). In another study, only 50\% of foals developed diarrhea during the second and third weeks of life, indicating that there was no relationship with the first postpartum heat (Kuhl et al., 2011).

Foal heat diarrhea has been related to different factors associated with the early establishment of microbiota, the development and maturation of the GIT, both induced by coprophagy, which helps in the colonization and change of the existing flora and by consumption of food other than milk. (Magdesian 2005; Kuhl et al., 2011).

\subsection{Feeding}

In humans, the early microbiota is mostly acquired from the mother through birth and breastfeeding (Gronlund et al., 1999). In foals between 0 and 3 days old, the intestinal microbiota is also similar to the microorganisms present in colostrum and milk (Quercia et al. 2019). Faubladier et al. (2013) observed forage intake in two-days-old foals. Over time, the foal gradually increases the consumption of forage at the same time it decreases the consumption of milk. Depending on the nutritional management, it also starts to eat concentrate (Lindemberg et al., 2019). An increase in bacteria related to fiber fermentation is observed from the moment foals start to eat concentrate, hay and pasture. As mantioned before, an increase in fiber fermenting bacteria has been reported in foals from 7 days to 2 weeks of life (Lindenberg et al. 2019; De La Torre et al., 2019). These changes are important for the stablishment of the adult microbiota. However, this entire process occurs gradually since the beginning of the foal's life (Lindemberg et al., 2019).

It is important to note that the stability of the intestinal microbiota can be altered due to sudden changes in the diet and according to the type of food offered. Increased consumption of large amounts of starch, for example, can lead to excessive proliferation of lactic acid-producing bacteria causing dysbiosis and potential related diseases (Garber, Hastie \& Murray, 2020). Diets rich in caloric nutrients lead to a decrease in microbial diversity and this can lead to a less stable environment, and, on the other hand, diets rich in forage are more diverse due to the types of microorganisms developed (Garber, Hastie \& Murray, 2020).

\subsection{Immune system and microbiota}

The development of the immune system in the foal begins during fetal life, where the presence of T lymphocytes can be identified already at 100 days of gestation and the presence of a small amount of immunoglobulins at 200 days (Giguere \& Polkes, 2005). The epitheliochorial diffuse placenta of the mare does not allow the passage of macromolecules including 
immunoglobulins from the mother to the fetus. Thus, foals are born with an insufficient amount of immunoglobulins (Jeffcott 1975; Guiguere \& Polkes, 2005). Although the foal has a responsive immune system at birth, it is extremely dependent on the transfer of passive immunity via maternal colostrum to mount an immediate immune response against any pathogen in the early days (Giguere \& Polkes, 2005).

Colostrum contains several important components for both the development of immunity and for intestinal maturation (Jeffcott, 1975). The peak of absorption of imunoglobulins by the foal occurs shortly after birth, and gradually decreases within 24 hours postpartum. This is mainly caused by the replacement of enterocytes capable of performing pinocytosis by mature enterocytes in the small intestine (Giguere \& Polkes, 2005). This process is essential for the development of mucosal immunity (Taschuck \& Griebel, 2012). Exposure to bacteria such as lactobacilli is also part of it and reduces the mucosal permeability (Taschuck \& Griebel, 2012). The main immunoglobulins present in equine colostrum are IgG, IgA and IgM (Giguere \& Polkes 2005). IgA plays a fundamental role in the intestine, preventing the adhesion of pathogenic bacteria to epithelial surfaces, control of bacterial populations by removing it through binding and stimulating mobility, and it also prevents inflammatory damage to the epithelial barrier (Taschuck \& Griebel, 2012; Alarcón, 2016).

The establishment of the microbiota is essential for the development of the intestinal immunity from the beginning of life and significantly influences the whole imune system in adulthood. This idea is in agreement with studies performed in rats free of microorganisms that demonstrated the development of an inefficient innate and adaptive imune response, including cytokine profile, when compared to animals under normal conditions (Taschuk \& Griebel, 2012; Purchiaroni et al., 2013).

During the development of the intestinal microbiota, its interaction with the host leads to the development of the intestinal immune system, since it has the function of differentiating pathogens from beneficial microorganisms, without changing the inflammatory response, which may impair the integrity of the mucosa of the organs (Alarcón, 2016). This symbiotic interaction is maintained through constant exposure to different microorganisms (Taschuk \& Griebel, 2012).

The interaction among commensal bacteria in the tract must be an extremely regulated mechanism to maintain balance of flora and, at the same time, to allow the defense against pathogenic microorganisms (Taschuk \& Griebel, 2012). Thus, intestinal immunity develops the ability to distinguish pathogen-associated molecular patterns (PAMPs) present in pathogenic microorganisms using typical resources of innate immunity through pattern recognition receptors (PRRs) (Purchiaroni et al., 2013). The regulation of the innate immune system occurs through the interaction of microbiota, intestinal cells and compartments, allowing the production of cytokines and consequently activation of $\mathrm{T}$ cells and adaptive immunity (Purchiaroni et al., 2013). The mucosal epithelium and luminous secretions complement the body's defense by working with innate and adaptive immunity, as for exemple the mucin secretion, which acts by binding to pathogens (Taschuk \& Griebel, 2012; Purchiaroni et al., 2013). When any part of this system fails, autoimmune or inflammatory diseases may develop, such as atopy and inflammatory diseases of the GIT, which result from an inappropriate inflammatory response to the microorganisms present in the intestine (Purchiaroni et al., 2013).

\subsection{Antimicrobial exposure}

As already discussed in the previous items, the balance of the intestinal microbiota is essential for health maintenance and dysbiosis may be an important factor in the excessive proliferation of pathogenic microorganisms leading to the development of diseases. Therefore, it has been demonstrated that the use of antimicrobials can promote dysbiosis and it has been associated with the development of diarrhea and colitis in horses (Gustafsson, 2004; Garber, Hastie \& Murray 2020). It is believed that when there are inbalances in the microbiota, opportunistic pathogens can proliferate more easily and cause disease (Harlow, Lawrence \& Flythe 2013). Changes in the microbiota may also lead to the deterioration of the protective layer of the mucosa that serves as a barrier. However, it is not known what damage it causes to the host (Garber, Hastie \& Murray, 
2020).

Costa et al. (2015) tested the administration of three antibiotics in healthy adult horses (procaine penicillin, ceftiofur and sulfadiazine with trimethoprim) and identified that although they all had some effect on the microbiota, sulfa with trimethoprim caused the greatest changes, mainly by decreasing bacteria from the phylum Verrumicrobiota, and increasing several genera of the phylum Firmicutes. In the same study, it was evaluated that 30 days were necessary for the microbiota to return to what it was previously to the administration of the drugs. Another study using ceftiofur and sulfadiazine with trimethoprim identified a decrease in cellulolytic bacteria and lactobacilli concomitantly with an increase in pathogenic bacteria such as Salmonella spp. and $C$. difficile, indicating that the administration of these antibiotics causes dysbiosis and allows the proliferation of pathogenic bacteria (Harlow, Lawrence and Flythe, 2013). In foals, antimicrobial therapy is widely used in order to reduce the risk of neonatal sepsis (COSTA, 2016), however; the impact of its use in this category is not known.

A recent study also investigated the presence of antimicrobial resistance genes linked to microbiota in less than onemonth-old healthy foals and found that the most common one was the tetracycline resistance gene, which is related to a greater abundance of Bacteroides in the microbiota, while genes of high clinical relevance, such as fluoroquinolones, were rarely found (Liu et al. 2020). The authors also suggested the occurrence of indirect exposure of foals to antibiotics through horizontal spread (Liu et al. 2020).

\section{Final Considerations}

Advances in sequencing technologies have allowed a better approach to the components and compartments involved in the initial colonization of the intestinal microbiota. In horses, studies have used these technologies to explore theories of vertical transmission and the relationship between maternal and fetal microbiota. Despite that, some limitations are still found and some facts remain unknown, as the colonization routes of the microbiota during the fetal period.

Neonatal microbiota colonization is a dynamic process and involves several scenarios linked to different maternal environments that are important in the early development of the GIT, in the modulation of the immune system and later in the stabilization of the microbiota for adult life. During this period, it is also significant to highlight the importance of the nutritional management to prevent illnesses. In addition, damages caused by the administration of antimicrobials drugs to the early microbiota of foals are not known, being an important subject to be investigated in the future.

\section{Acknowledgments}

We thank CAPES (Coordenação de Aperfeiçoamento Pessoal de Nível Superior) for providing the scholarships.

\section{References}

Aagaard, K., Ganu, R., Ma, J., Hu, M., Miller, L., Jobe, A., Kallapur, S. \& Chougnet, C. (2013). Intraamniotic interleukin-1 (IL1ß) induces histologic chorioamnionitis and alters the microbiome in a primate model of inflammatory preterm birth. American Journal of Obstetrics and Gynecology 208 : S218.

Aagaard, K., Ma, J., Antony, K., Ganu, R., Petrosino, J. \& Versalovic, J. (2014). The placenta harbors a unique microbiome. Science Translational Medicine, 6: $1-11$.

Alarcón, P., González, M. \& Castro, É. (2016). Rol de la microbiota gastrointestinal en la regulación de la respuesta inmune. Revista médica de Chile, 144(7), 910-916.

Backhed, F. R., Ding, H., Wang, T., Hooper, L. V., Koh, G. Y., Nagy, A., Semenkovich, C. F. \& Gordon, J. I. (2004). The gut microbiota as an environmental factor tha regulates fat storage. Proceedings of the National Academy of Sciences, 101(44):15718-23.

Bäckhed, F. R., Roswall, J., Peng, Y., Feng, Q., Jia, H., Kobatcheva-Datchary, P., Li, Y. Xia, Y., Xie, H., Zhong, H., Tanweer, K., Zhang, J., Li, J., Xiao, L., Al-Aama, J., Zhang, D., Lee, Y. S., Kotowska, D., Colding, C., Tremarolli, V., Yin, Y., Bergman, S., Xu, X., Madsen, L., Kristiansen, K., Dahlgren, J. \& Wang, J. (2015).. Dynamics and Stabilization of the Human Gut Microbiome during the First Year of Life. Cell Host Microbe. $17(6)$ : 852. 
Bordin, A. I., Suchodolski, J. S., Markel, M. E., Weaver, K. B., Steiner, J. M., Dowd, S. E., Pillai, S. \& Cohen, N. D. (2013). Effects of Administration of Live or Inactivated Virulent Rhodococccus equi and Age on the Fecal Microbiome of Neonatal Foals. Plos One. 8(6):e66640.

Costa, M. C., Stämpfli, H. R., Allen-Vercoe, E. \& Weese, J. S. (2016). Development of the faecal microbiota in foals. Equine veterinary journal, 48(6), 681688.

Costa, M. C., Stämpfli, H. R., Arroyo, L. G., Allen- Vercoe, E., Gomes, R. G. \& Weese, J. S. (2015). Changes in the equine fecal microbiota associated with the use of systemic antimicrobial drugs. BMC Veterinary Research, 11:19.

Costa, M. C. \& Weese, J. S. (2012). The equine intestinal microbiome. Animal Health Research Reviews, 13(1); 121-128.

Cobb, C. M., Kelly, P. J., Williams, K. B., Babbar, S., Angolkar, M. \& Derman, R. J. (2017). The oral microbiome and adverse pregnancy outcomes. International Journal of Women's Health, 9: 551-559.

Crowell-Davis, S. L., Caudle, A. B. (1989). Coprophagy by foals: recognition of maternal feces. Applied Animal Behaviour Science. 24(3): 267-272.

Crowell-Davis, S. L. \& Houpt, K. A. (1985). Coprophagy by foals: effect of age and possible functions. Equine Veterinary Journal. 17: 17-19.

De La Torre, U., Henderson, J. D., Furtado, K. L., Pedroja, M., Elenamarie, O., Mora, A., Pechanec, M. Y., Maga, E. A \& Mienaltowski, M. J. (2019). Utilizing the fecal microbiota to understand foal gut transitions from birth to weaning. Plos One, 14(4): 02216211.

Earing, J. E., Durig, A. C., Gellin, G. L., Lawrence, L. M. \& Flythe, M. D. (2012). Bacterial Colonization of the Equine Gut; Comparison of Mare and Foal Pairs by PCR-DGGE*. Advances in Microbiology, 2: 79-86.

Fanaro, S., Chierici, R., Guerrini, P., \& Vigi, V. (2003). Intestinal microflora in early infancy: composition and development. Acta paediatrica, 92, 48-55.

Faubladier, C., Julliand, V., Danel, J., Philippeau, C. (2013). Bacterial carbohydrate-degrading capacity in foal faeces: changes from birth to pre-weaning and the impact of maternal supplementation with fermented feed products. British Journal of Nutrition, 110: 1040-1052

Fernandes, K. A., Kittelmann, S., Rogers, C. W., Gee E. K, Bolwell, C. F., Bermingham E. N. \& Thomas, D. G. (2014). Faecal Microbiota of Forage-Fed Horses in New Zealand and the Population Dynamics of Microbial Communities following Dietary Change. PLoS ONE, 9(11): e112846.

Flemer, B., Gaci, N., Borrel, G., Sanderson, I. R., Chaudhary, P. P., Tottey, W., O’Toole, P. W. \& Brugère, J-F. (2017). Fecal microbiota variation across the lifespan of the healthy laboratory rat. Gut Microbes, 8(5):428-439.

Garber, A., Hastie, P., Murray, J-A. (2020). Factors Influencing Equine Gut Microbiota: Current Knowledge. Journal of Equine veterinary Science. 88: 102943.

Giguère, S. \& Polkes, A. C. (2005). Immunologic Disorders in Neonatal Foals. Veterinary Clinics: Equine Practice, 21: $241-272$.

Gosalbes, M. J., Llop, S., Vallès, Y., Moya, A., Ballester, F. \& Francino M. P. (2013). Meconium microbiota types dominated by lactic acid or enteric bacteria are differentially associated with maternal eczema and respiratory problems in infants. Clinical \& Experimental Allergy, (43): $198-211$.

Gronlund, M. M., Salminen, S., Mykkanen, H., Kero, P., Lehtonen, O. P. Development of intestinal bacterial enzymes in infants- relationship tom ode of delivery and type of feeding. APMIS, 107(7):655-60.

Gustafsson, A. (2004). Antibiotic Associated Diarrhea in Horses, with special reference to Clostridium difficile. Doctoral thesis. Swedish University of Agricultural Sciences, Uppsala.

Harlow, B. E., Lawrence, L. M. \& Flythe, M. D. (2013). Diarrhea-associated pathogens, lactobacilli and cellulolytic bacteria in equine feces: responses to antibiotic challenge. Veterinary Microbiology. 166, 225-232.

Hemberg, E., Einarsson, S., Kútvölgyi, G., Lundeheim, N., Bagge, E., Båverud, V., Jones, B. \& Morrell, J. M. (2015). Occurrence of bacteria and polymorphonuclear leukocytes in fetal compartments at parturition; relationships with foal and mare health in the peripartum period. Theriogenology, $84(1)$ : 163-169.

Husso, A., Jalanka, J., Alipour, M. J., Huhti, P., Kareskoski, M., Pessa-Morikawa, T., Livanainen A \& Niku, M. (2020). The composition of the perinatal intestinal microbiota in horse. Scientific Reports, 10(1), 1-12.

Jacquay, E., Zeglin, L., Lillich, J., Jones, E. \& Kouba, J. (2018). Characterization of Foal Fecal Microbiome from Birth to Weaning and the Relationship to Mare Milk and Mare Feces. Journal of Animal Science, 96(2):33.

Jeffcott, L. B. (1975). The transfer of passive immunity to the foal and its relation to immune status after birth. Journal of reproduction and fertility, 23(23):727-33.

Johnston, R. H., Kamstra, L. D. \& Kohler, P. H. (1970). Mares’ Milk Composition as Related to "Foal Heat” Scours. Journal of Animal Science, 31(3), 549553.

Kuhl, J., Winterhoff, N., Wulf, M., Schweigert, F. J., Schwendenwein, I., Bruckmaie,r R. M., Aurich, J., Kutzer, P. \& Aurich, C. (2011). Changes in faecal bacteria and metabolic parameters in foals during the first six weeks of life. Veterinary Microbiology, 151(3-4): 321-328.

Lindenberg, F., Krych, L., Kot, W., Fielden, J., Frøkiær, H., van Galen, G., Nielsen, D. S. \& Hansen, A.K. (2019). Development of the equine gut microbiota. Scientific reports, 9(1), 1-9.

Liu, Y., Bailey, K. E., Dyall- Smith, M., Marenda, M. S., Hardefeldt, L. Y., Browning, G. F., Gilkerson, J. R. \& Billman-Jacobe, H. Faecal microbiota and antimicrobial resistance gene profiles of healthy foals (2020). Equine Veterinary Journal, 00:1-11. 
Magdesian, K. G. (2015). Neonatal foal diarrhea. Veterinary Clinics: Equine Practice, 21, 295-312

Mols, K. L., Boe-Hansen, G. B., Mikkelsen, D., Bryden, W. L., Cawdell- Smith, A. J. (2020). Prenatal establishment of the foal gut microbiota: a critique of the in utero colonisation hypothesis. Animal Production Science, 60: 2080-2092.

Moreau, M. M., Eades, S. C., Reinemeyer, C. R., Fugaro, M. N. and Onishi, J. C. (2014). Illumina sequencing of the V4 hypervariable region 16S rRNA gene reveals extensive changes in bacterial communities in the cecum following carbohydrate oral infusion and development of early-stage acute laminitis in the horse. Veterinary Microbiology, 168, 436-441.

Pereira, A. S., Shitsuka, D. M., Parreira, F. J. \& Shutsuka, R. (2018). Metodologia da pesquisa científica, $1^{\text {o }}$ Edição UBA/NTE/UFSM, Universidade Federal de Santa Maria.

Prince, A. L., Chu, D. M., Seferovic, D. M., Antony, K. M., Ma, J. \& Aagaard, K. M. (2015). The perinatal microbiome and pregnancy: Moving beyond the vaginal microbiome. 5(6): a023051.

Purchiaroni, F., Tortora, A., Gabrielli, M., Gabrielli, M., Bertucci, F., Gigante, G., Ianiro, G., Ojetti, V., Scarpellini, E. \& Gasbarrin, A. (2013). The role of intestinal microbiota and the immune system. European Review for medical and Pharmacological Sciences, 17: 323-333.

Pyles, M. B., Hayes, S., Crum, A., Kunes, M., Radomski, E., Flythe, M. \& Lawrence, L. (2020). Detecting coprophagy in foals and its relationship with foal gut helth. Journal of Animal Science, 98(4): 91-92.

Quercia, S., Freccero, F., Castagnetti, C., Soverini, M., Turroni, S., Biagi, E., Rampelli, S., Lanci, A., Mariella, J., Chinellato, E., Brigidi, P \& Candela, M. (2019). Early colonisation and temporal dynamics of the gut microbial ecosystem in Standardbred foals. Equine Veterinary Journal, 1 (2):231-237.

Russell, S. L., Gold, M. J., Willing, B. P., Thorson, L., McNagny, K. M. and Finlay, B. B. (2013). Perinatal antibiotic treatment affects murine microbiota, immune responses and allergic asthma. Gut Microbes, 4: 158-164.

Saad, S. M. I. (2006). Probióticos e prebióticos: o estado da arte. Revista Brasileira de Ciências Farmacêuticas, 42(1), 1-16.

Schoster, A., Staempfli, H. R., Guardabassi, L. G., Jalali, M. \& Weese, J. S. (2017). Comparison of the fecal bacterial microbiota of healthy and diarrheic foals at two and four weeks of life. BMC Veterinary Research, 13: 144.

Steel, J. H., Malatos, S., Kennea, N., Edwards, A. D., Miles, L., Duggan, P., Reynolds, P. R., Feldman, R. G. \& Sullivan, M. H. F. (2005). Bacteria and Inflammatory Cells in Fetal Membranes Do Not Always Cause Preterm Labor. Pediatric Research, 57(3): $404-411$.

Steelman, S. M., Chowdharu, B. P., Dowd, S., Suchodolski, J. \& Janecka, J. (2012). Pyrosequencing of 16S rRNA genes in fecal samples reveals high diversity of hindgut microflora in horses and potential links to chronic laminitis, BMC Veterinary Research, 8:231.

Taschuk, R. \& Griebel, P. J. (2012). Commensal microbiome effects on mucosal immune system development in the ruminant gastrointestinal tract. Animal Health Research Reviews, 13(1); 129-141.

Tavanner, M. K., McDonnell, S. M. \& Biddle, A. S. (2020). Development of the equine hindgut microbiome in semi-feral and domestic conventionallymanaged foals. Animal Microbiome, 2:43.

Toh, M. C. \& Allen-Vercoe E. (2015). The human gut microbiota with reference to autism spectrum disorder: considering the whole as more than a sum of its parts. Microbial Ecology in Health and Disease, 26:26309.

Tonini, I. G. O., Vaz, D. S. S. \& Mazur, C. E. (2020). Gut-brain axis: relationship between intestinal microbiota and mental disorders. Research, Society and Development, 9(7), e499974303.

Turnbaugh, P. J., Hamady, M., Yatsunenko, T., Cantarel, B. L., Duncan, A., Ley, R .E., Sogin, M. L., Jones, W. J., Roe, B. A., Affourtit, J. P., Egholm, M., Henrissat, B., Heath, A. C., Knight, R. and Gordon, J. I. (2009) A core gut microbiome in obese and lean twins. Nature, 457, $480-484$.

Weese, J. S., Holcombe, S. J., Embertson R. M., Kurtz, K. A., Roessner, H. A., Jalali, M. \& Wismer, S. E. (2015). Changes in the faecal microbiota of mares precede the development of post partum colic. Equine Veterinary Journal, 47: 641-649. 